\title{
Synthesis and Characterization of the Germathioacid Chloride Coordinated by an $\mathrm{N}$-Heterocyclic Carbene $\S$
}

\author{
Yasunobu Egawa ${ }^{1, *, \dagger}$, Chihiro Fukumoto ${ }^{1}$, Koichiro Mikami ${ }^{2}$ (D), Nobuhiro Takeda ${ }^{1}$ \\ and Masafumi Unno ${ }^{1, *}$ \\ 1 Department of Chemistry and Chemical Biology, Graduate School of Science and Technology, \\ Gunma University, Kiryu, Gunma 376-8515, Japan; t161a085@gunma-u.ac.jp (C.F.); \\ ntakeda@gunma-u.ac.jp (N.T.) \\ 2 Functional Polymer Group, Sagami Chemical Research Institute, 2743-1 Hayakawa, Ayase, \\ Kanagawa 252-1193, Japan; koichiro.mikami@sagami.or.jp \\ * Correspondence: nobu_egawa@jamstec.go.jp (Y.E.); unno@gunma-u.ac.jp (M.U.); \\ Tel.: +81-46-863-9659 (Y.E.); +81-277-30-1230 (M.U.) \\ + Present Address: Frontier Research Group, Research and Development (R\&D) Center for Marine Bioscience, \\ Japan Agency for Marine-Earth Science and Technology (JAMSTEC), 2-15 Natsushima-cho, Yokosuka, \\ Kanagawa 237-0061, Japan. \\ $\S$ Dedicated to Prof. Dr. Robert West in honors of his 90th birthday.
}

Received: 28 June 2018; Accepted: 1 August 2018; Published: 3 August 2018

\begin{abstract}
Carboxylic acid chlorides are useful substrates in organic chemistry. Many germanium analogues of carboxylic acid chloride have been synthesized so far. Nevertheless, all of the reported germathioacid chlorides use bidentate nitrogen ligands and contain germanium-nitrogen bonds. Our group synthesized germathioacid chloride, $\mathrm{Ge}(\mathrm{S}) \mathrm{Cl}\left\{\mathrm{C}_{6} \mathrm{H}_{3}-2,6-\mathrm{Tip}_{2}\right\}\left(\mathrm{Im}-i-\mathrm{Pr}_{2} \mathrm{Me}_{2}\right)$, using $N$-heterocyclic carbene ( $\left(\mathrm{Im}-i-\mathrm{Pr}_{2} \mathrm{Me}_{2}\right)$. As a result of density functional theory (DFT) calculation, it was found that electrons are localized on sulfur, and the germanium-sulfur bond is a single bond with a slight double bond property.
\end{abstract}

Keywords: germanium; germanethione; germathioacid chloride; $N$-heterocyclic carbines

\section{Introduction}

Heavier analogues of multiple bonded organic species have attracted the interest of many chemists in terms of comparisons for structures, physical properties, and reactivities [1-3]. For a long time, multiple bonds of higher row main group elements have been thought to be unstable due to the small overlap of $\pi$-orbitals. However, a breakthrough occurred in 1981 with the achievement of the synthesis of $\mathrm{Si}=\mathrm{C}[4], \mathrm{S}=\mathrm{Si}[5]$, and $\mathrm{P}=\mathrm{P}[6]$ bonds by taking advantage of the protection by bulky substituents. They have also opened a breach in the elemental bond theory. In recent years, increasing interest in the chemistry of double-bonded species between group 14 and 16 elements has emerged, since carbonyl compounds represent one of the most important functionalities in chemistry [3,7,8]. Among them, focusing on the double bond of germanium and sulfur, that is, germanetione, there is a history of research as shown below (Figure 1). 


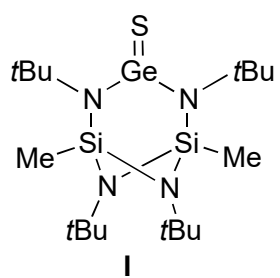

2.063(3) $\AA$

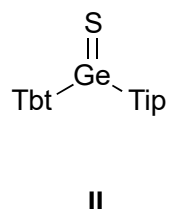

$2.049(3) \AA$<smiles>CC(C)c1cc(C(C)C)c(C(C)C)c(C(C)C)c1</smiles>

Tbt<smiles>[R]c1cc(C(C)C)c(C(C)C)c(C(C)C)c1</smiles>

Tip $\mathrm{R}=i \mathrm{Pr}$

Dip $\mathrm{R}=\mathrm{H}$<smiles></smiles>

III 2.053(6) ^<smiles></smiles>

IV 2.048(2) A

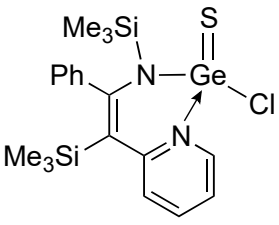

v

2.056(2) A<smiles></smiles>

VI

$2.065(1) \AA$

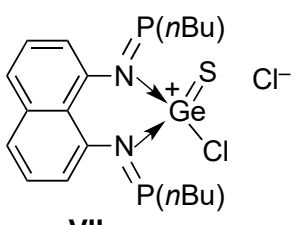

VII

2.066(1) A

Figure 1. $\mathrm{Ge}=\mathrm{S}$-containing compounds and $\mathrm{Ge}=\mathrm{S}$ bond length .

In 1989, Veith and co-workers synthesized germanethione (I) (germanium urea), which was stabilized by nitrogen ligand, and determined its structure by X-ray analysis [9]. After that, Okazaki, Tokitoh and co-workers isolated the first diarylgermanethione (II) using a very bulky protecting group and determined its structure [10,11]. Meanwhile, in organic chemistry, carboxylic acid chloride is an important compound group that serves as a substrate for the Friedel-Crafts reaction or Rosenmund reduction. The development of heavy analogues of carboxylic acid chloride was achieved by Roesky's group in 2002. They succeeded in the synthesis and isolation of the target substance (III) by thermodynamic stabilization using a $\pi$-diketiminate ligand [12]. Following their work, several results of germathioacid chloride syntheses using a bidentate nitrogen ligand have been reported (IV-VII) [13-16]. Nevertheless, due to the limitation of the use of a bidentate nitrogen ligand, all germathioacid chloride syntheses reported so far are only those in which nitrogen atoms and germanium are bonded; thus, all are heavy analogues of carbamoyl chloride.

In this paper, we report the synthesis and structure of germathioacid chloride stabilized with an NHC ligand. Among germathioacid chlorides, this is the first example containing a germanium carbon bond. We have clarified the bonding state of the germathioacid chloride by density functional theory (DFT) calculation.

\section{Results and Discussion}

\subsection{Synthesis and Structure of Germathioacid Chloride 3}

As shown in Scheme 1, 1,3-diisopropyl-4,5-dimethylimidazol-2-ylidene (Im- $i$ - $\left.\operatorname{Pr}_{2} \mathrm{Me}_{2}\right)$-substituted chlorogermylene (2) was prepared by the reaction of the $\mathrm{Ge}(\mathrm{Cl})\left\{\mathrm{C}_{6} \mathrm{H}_{3}-2,6-\mathrm{Tip}_{2}\right\}$ (1) with an equivalent amount of Im-i-Pr $\mathrm{Pe}_{2}$ in dry toluene. This synthesis method was based on Filippou's method [17]. Compound 2 was treated with sulfur element in dry benzene- $d_{6}$ at ambient temperature for 3 days, and after work up, the germathioacid chloride coordinated by $\operatorname{Im}-i-\operatorname{Pr}_{2} \mathrm{Me}_{2}$ (3), $\mathrm{Ge}(\mathrm{S}) \mathrm{Cl}\left\{\mathrm{C}_{6} \mathrm{H}_{3}-2,6-\mathrm{Tip}_{2}\right\}\left(\mathrm{Im}-i-\mathrm{Pr}_{2} \mathrm{Me}_{2}\right.$ ) was obtained in $31 \%$ yield. The germathioacid chloride (3) was characterized by NMR spectroscopy together with elemental analysis, and the structure of 3 was finally determined by single-crystal X-ray analysis (Figure 2). 


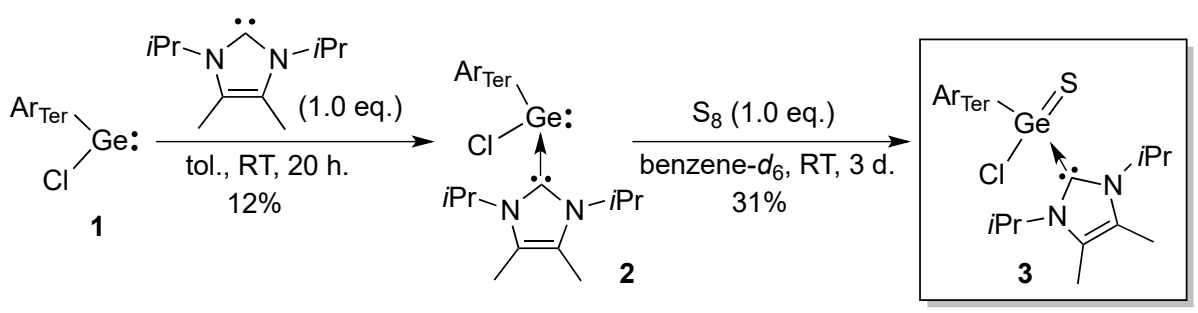

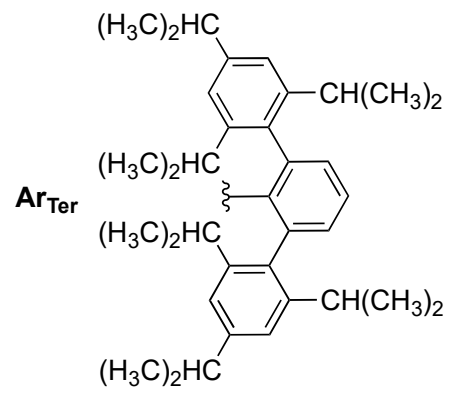

Scheme 1. Synthesis of $\mathrm{Ge}(\mathrm{S}) \mathrm{Cl}\left\{\mathrm{C}_{6} \mathrm{H}_{3}-2,6-\mathrm{Tip}_{2}\right\}\left(\operatorname{Im}-i-\mathrm{Pr}_{2} \mathrm{Me}_{2}\right) 3$.

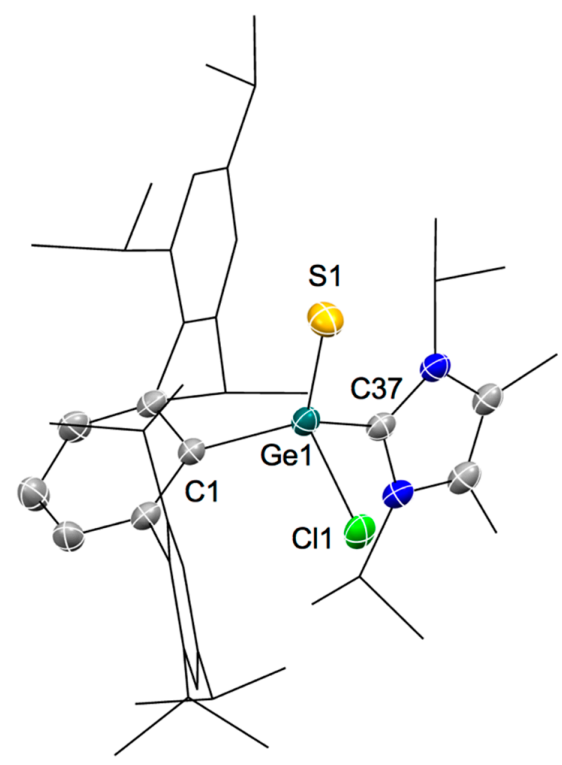

Figure 2. Molecular structure of $\mathrm{Ge}(\mathrm{S}) \mathrm{Cl}\left\{\mathrm{C}_{6} \mathrm{H}_{3}-2,6-\mathrm{Tip}_{2}\right\}\left(\mathrm{Im}-i-\mathrm{Pr}_{2} \mathrm{Me}_{2}\right)$ 3, with thermal ellipsoids shown at the $50 \%$ probability level. Hydrogen atoms are omitted for clarity. Ge: Green, S: Yellow, $\mathrm{Cl}$ : Light green, N: Blue, C: gray. Selected bond distances $(\AA)$ and angles $\left({ }^{\circ}\right)$ : Ge1-S1 2.0846(8), Ge1-C11 1.991(3), Ge1-C37 2.060(3), Ge1-Cl 2.2261(7); C1-Ge1-C37 108.65(10), C37-Ge1-Cl1 95.26(7), C1-Ge1-Cl1 106.70(7), C1-Ge1-S1 102.04(8), C37-Ge1-S1 104.82(8), S1-Ge1-Cl1 108.17(3).

Crystals suitable for X-ray crystallographic analysis of 3 were obtained from benzene- $d_{6}$. Compound (3) crystallized in the monoclinic crystal system with $P 2_{1} / n$ space group. Compound (3) is the first example of germathioacid chloride in which the Ge atom is not coordinated to an $\mathrm{N}$ atom. The germanium center is bonded to the terphenyl ligand, chlorine, and sulfur atoms, and the other site is occupied by the NHC $\left(\mathrm{Im}-i-\mathrm{Pr}_{2} \mathrm{Me}_{2}\right)$, resulting in a tetrahedral geometry at the germanium center. The Ge-S bond of $3(2.0846(8) \AA)$ is slightly longer than the $\mathrm{Ge}=\mathrm{S}$ bonds stabilized by $\mathrm{N}$ ligands

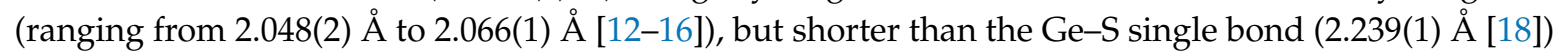
(Figure 1). This result suggests that the Ge-S bond has a partial double bond character. 


\subsection{Density Functional Theory Studies on the Germathioacid Chloride 3}

In order to better understand the characteristics of germathioacid chloride $\mathbf{3}$, a density functional theory (DFT) calculation (B3LYP/6-31G(d,p)) was carried out [19]. The optimized structure of the germathioacid chloride 3 well-reproduced the structure experimentally observed in single-crystal X-ray analysis (Figure 2 and Figure S3). The natural population analysis (NPA) showed that a large positive charge was located on $\mathrm{Ge}(+1.240)$, and the $\mathrm{S}$ atom and $\mathrm{Cl}$ atom had negative charges of -0.762 and -0.456 , respectively. The calculated IR stretching frequency of $G=S$ bond was $469.64 \mathrm{~cm}^{-1}$.

As shown in Figure 3, the highest occupied molecular orbital (HOMO) and HOMO - 1 were predominantly localized on the $S$ atom, which should correspond to non-bonding pair electrons (Figure $3 a, b)$, and an $\pi$-bond between the Ge atom and the $S$ atom was not observed. The molecular orbitals (MOs), which should correspond to the $\sigma$-bonds of the $\mathrm{Ge}-\mathrm{S} / \mathrm{Ge}-\mathrm{C}(\mathrm{NHC})$, and the $\sigma^{*}$-bonds of the Ge-S/Ge-Cl were also observed in HOMO - 1/HOMO - 29 (Figure 3c,d) and LUMO + 8, respectively (Figure 3e). These results suggest that the $\mathrm{Ge}-\mathrm{S}$ bond would have a single bond character. On the other hand, the value of the Wiberg Bond Index (WBI) of Ge-S is 1.367, implying that the Ge-S bond has a partial double bond character. Although the value of WBI seemingly contradicted the analysis of the MOs, the second-order perturbation theory analysis rationalized the Ge-S bond feature; both non-bonding pair electrons localized on the $S$ atom donated stabilization energy to the $\sigma^{*}$-orbitals of the $\mathrm{Ge}-\mathrm{Cl}(23.39 \mathrm{kcal} / \mathrm{mol}), \mathrm{Ge}-\mathrm{C}\left(\mathrm{Ar}_{\mathrm{Tip}}\right)(11.23 \mathrm{kcal} / \mathrm{mol})$, and $\mathrm{Ge}-\mathrm{C}(\mathrm{NHC})(16.51 \mathrm{kcal} / \mathrm{mol})$, respectively, and the secondary orbital interaction should be attributed to the partial $\pi$-bonding nature between the Ge-S bond in the WBI analysis. These results indicate that the Ge-S bond is a single bond with a partial double bond character, which is in good agreement with observation that the bond length (2.0846(8) $\AA$ ) in the germathioacid chloride 3 (Figure 2) is shorter than that of the single bond of

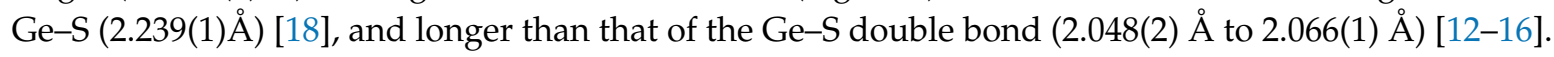

(a)

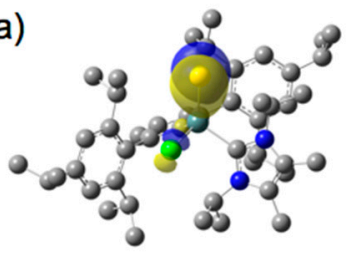

(c)

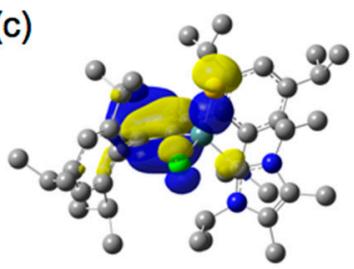

(b)

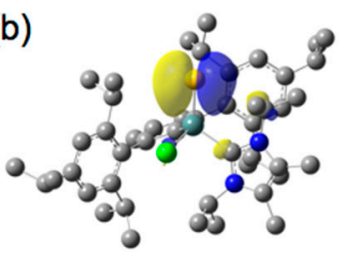

(d)

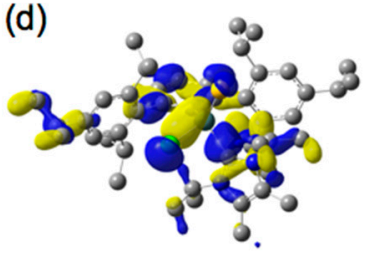

(e)

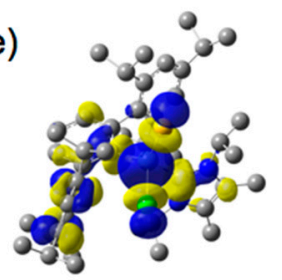

Figure 3. Selected molecular orbitals and their energy levels (eV): (a) $\mathrm{HOMO}(-4.815 \mathrm{eV}),(\mathbf{b}) \mathrm{HOMO}-$ $1(-4.925 \mathrm{eV}),(\mathbf{c}) \mathrm{HOMO}-7(-6.6529 \mathrm{eV}),(\mathbf{d}) \mathrm{HOMO}-29(-9.1961 \mathrm{eV}),(\mathbf{e}) \mathrm{LUMO}+8(-0.6615 \mathrm{eV})$.

Based on experiments and calculation results, compound 3 could be an intermediate property between $3^{\prime}$ and $3^{\prime \prime}$ (Figure 4). Further investigation will be carried out in the future.

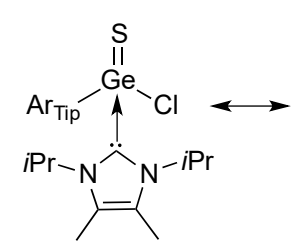

3

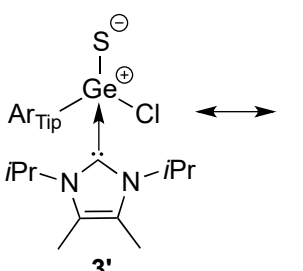

3'

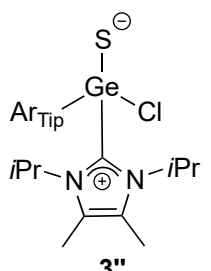

3"

Figure 4. Resonant structural formula of 3. 


\section{Materials and Methods}

\subsection{General Information}

Materials: All manipulations were carried out under an argon atmosphere using standard Schlenk-line or glove-box techniques. Hexane, ether, and THF were dried by being passed through columns of activated alumina and a supported copper catalyst supplied by Nikko Hansen \& Co., Ltd. (Osaka, Japan). Toluene was refluxed over sodium and benzophenone, distilled, and degassed prior to use. Deuterated benzene $\left(\mathrm{C}_{6} \mathrm{D}_{6}\right.$, benzene- $\left.d_{6}\right)$ was dried and degassed over a potassium mirror in vacuo prior to use. $\left(\mathrm{Et}_{2} \mathrm{O}\right) \mathrm{LiC}_{6} \mathrm{H}_{3}-2,6-\mathrm{Tip}_{2}$ [20], $\mathrm{Ge}(\mathrm{Cl})\left\{\mathrm{C}_{6} \mathrm{H}_{3}-2,6-\mathrm{Tip}_{2}\right\}$ [21] and 1,3-diisopropyl-4,5-dimethylimidazol-2-ylidene ( $\left(\mathrm{Im}-i-\mathrm{Pr}_{2} \mathrm{Me}_{2}\right)$ [22] were prepared according to procedures published in the literature.

The Fourier transformation nuclear magnetic resonance (NMR) spectra were obtained using JEOL JNM-ECS $300\left({ }^{1} \mathrm{H}\right.$ at $300 \mathrm{MHz},{ }^{13} \mathrm{C}$ at $\left.75 \mathrm{MHz}\right)$ and JEOL JNM-ECA $600\left({ }^{1} \mathrm{H}\right.$ at $600 \mathrm{MHz},{ }^{13} \mathrm{C}$ at $\left.151 \mathrm{MHz}\right)$ NMR instruments (JEOL, Tokyo, Japan). For ${ }^{1} \mathrm{H}-\mathrm{NMR}$, chemical shifts are reported as $\delta$ units (ppm) relative to $\mathrm{SiMe}_{4}$ and the residual solvents peaks were used as standards. Analysis by electron impact mass spectrometry (EI-MS) was performed on a SHIMADZU GCMS-QP2010SE/DI2010 (SHIMADZU, Kyoto, Japan). Elemental analyses were performed by the Center for Material Research by Instrumental Analysis (CIA), Gunma University, Japan.

\subsection{Synthesis}

\subsubsection{Synthesis of $\mathrm{Ge}(\mathrm{Cl})\left\{\mathrm{C}_{6} \mathrm{H}_{3}-2,6-\mathrm{Tip}_{2}\right\}\left(\mathrm{Im}-i-\mathrm{Pr}_{2} \mathrm{Me}_{2}\right) 2$}

To a solution of $\mathrm{Ge}(\mathrm{Cl})\left\{\mathrm{C}_{6} \mathrm{H}_{3}-2,6-\mathrm{Tip}_{2}\right\}(249 \mathrm{mg}, 0.423 \mathrm{mmol})$ in dry toluene $(3 \mathrm{~mL})$ was added 1,3-diisopropyl-4,5-dimethlylimidazol-2-ylidene $(76.3 \mathrm{mg}, 0.423 \mathrm{mmol})$ in dry toluene $(6 \mathrm{~mL})$ at room temperature under an argon atmosphere. The solution was stirred for $20 \mathrm{~h}$. The resulting solution was concentrated under reduced pressure. Then, toluene was added for crystallization to afford 2 as colorless crystals (yield: $24.4 \mathrm{mg}, 12 \%$ ).

2: colorless crystals; ${ }^{1} \mathrm{H}-\mathrm{NMR}\left(300 \mathrm{MHz}, \mathrm{C}_{6} \mathrm{D}_{6}, 70^{\circ} \mathrm{C}, \delta\right.$ in ppm) $\delta 0.98$ (broad, $\left.6 \mathrm{H}\right) 1.04$ (broad, $\left.6 \mathrm{H}\right)$, $1.11(d, J=6.8 \mathrm{~Hz}, 6 \mathrm{H}), 1.16(d, J=6.8 \mathrm{~Hz}, 6 \mathrm{H}), 1.26(d, J=6.8 \mathrm{~Hz}, 6 \mathrm{H}), 1.31(d, J=6.8 \mathrm{~Hz}, 6 \mathrm{H}), 1.33$ $(d, J=6.8 \mathrm{~Hz}, 6 \mathrm{H}), 1.58(\mathrm{~s}, 6 \mathrm{H}), 1.64(d, J=6.8 \mathrm{~Hz}, 6 \mathrm{H}), 2.91(\mathrm{sept}, J=6.8 \mathrm{~Hz}, 2 \mathrm{H}), 3.19(\mathrm{sept}, J=6.8 \mathrm{~Hz}$, 2H), 3.38 (sept, $J=6.8 \mathrm{~Hz}, 2 \mathrm{H}), 5.39$ (broad, $2 \mathrm{H}), 6.96-7.12(\mathrm{~m}, 3 \mathrm{H}), 7.23(\mathrm{~s}, 4 \mathrm{H}) ;{ }^{13} \mathrm{C}\left\{{ }^{1} \mathrm{H}\right\}-\mathrm{NMR}(151$ $\mathrm{MHz}, \mathrm{C}_{6} \mathrm{D}_{6}, \mathrm{RT}, \delta$ in ppm) $\delta 10.2\left(\mathrm{CH}_{3}\right), 20.6\left(\mathrm{CH}_{3}\right), 21.7\left(\mathrm{CH}_{3}\right), 22.6\left(\mathrm{CH}_{3}\right), 23.4\left(\mathrm{CH}_{3}\right), 24.4\left(\mathrm{CH}_{3}\right)$, $24.5\left(\mathrm{CH}_{3}\right), 24.6\left(\mathrm{CH}_{3}\right), 26.2\left(\mathrm{CH}_{3}\right), 26.5\left(\mathrm{CH}_{3}\right), 30.9(\mathrm{CH}), 31.2(\mathrm{CH}), 31.4(\mathrm{CH}), 31.5(\mathrm{CH}), 34.6(\mathrm{CH})$, $34.9(\mathrm{CH}), 52.2(\mathrm{CH}), 52.8(\mathrm{CH}), 120.8(\mathrm{CH}), 121.0(\mathrm{CH}), 121.2(\mathrm{CH}), 125.0(\mathrm{CH}), 125.7(\mathrm{CH}), 126.3(\mathrm{CH})$, $128.3(\mathrm{CH}), 129.3(\mathrm{C}), 131.8(\mathrm{C}), 140.0(\mathrm{C}), 147.1(\mathrm{C}), 147.6(\mathrm{C}), 156.9(\mathrm{C}), 172.3(\mathrm{C})$; Anal. Calcd. for $\mathrm{C}_{47} \mathrm{H}_{69} \mathrm{ClGeN}_{2}$ : C 73.30, H 9.03, N 3.64; found: C 73.01, H 8.94, N 3.61.

\subsubsection{Synthesis of $\mathrm{Ge}(\mathrm{S}) \mathrm{Cl}\left\{\mathrm{C}_{6} \mathrm{H}_{3}-2,6-\mathrm{Tip}_{2}\right\}\left(\mathrm{Im}-i-\mathrm{Pr}_{2} \mathrm{Me}_{2}\right) 3$}

To a solution of $\mathrm{Ge}(\mathrm{Cl})\left\{\mathrm{C}_{6} \mathrm{H}_{3}-2,6-\mathrm{Tip}_{2}\right\}\left(\mathrm{Im}-i-\mathrm{Pr}_{2} \mathrm{Me}_{2}\right)(90.6 \mathrm{mg}, 0.118 \mathrm{mmol})$ (2) in benzene- $d_{6}$ $(0.5 \mathrm{~mL})$ in an NMR tube equipped with a Young stopcock at room temperature, $\mathrm{S}_{8}(3.77 \mathrm{mg}$, $0.118 \mathrm{mmol}$ ) was added. The solution was reacted for 3 day in the NMR tube. The resulting solution was concentrated under reduced pressure to yield colorless crystals of 3 (yield: $28.9 \mathrm{mg}, 31 \%$ ).

3: colorless crystals; ${ }^{1} \mathrm{H}-\mathrm{NMR}\left(600 \mathrm{MHz}, \mathrm{C}_{6} \mathrm{D}_{6}, \mathrm{RT}, \delta\right.$ in ppm) $\delta 0.34$ (broad, $\left.3 \mathrm{H}\right), 0.50$ (broad, $\left.3 \mathrm{H}\right), 0.94$ (broad, 3H), 0.98 (broad, 3H), 1.04 (broad, 3H), 1.06 (broad, 3H), 1.16 (broad, 3H), 1.20 (broad, 3H), 1.30 (broad, 6H), 1.36 (broad, 12H), 1.49 (broad, 3H), 1.55 (broad, 3H), 1.97 (broad, 3H), 2.02 (broad, 3H), 2.64 (broad, 1H), 2.86 (broad, 1H), 2.97 (broad, 1H), 3.06 (broad, 1H), 3.73 (broad, $1 \mathrm{H}), 3.97$ (broad, $1 \mathrm{H})$, 5.38 (broad, $1 \mathrm{H}), 6.92-7.02(\mathrm{~m}, 4 \mathrm{H}), 7.35-7.44(\mathrm{~m}, 3 \mathrm{H}), 7.75$ (broad, $1 \mathrm{H}) ;{ }^{13} \mathrm{C}\left\{{ }^{1} \mathrm{H}\right\}-\mathrm{NMR}\left(151 \mathrm{MHz}, \mathrm{C}_{6} \mathrm{D}_{6}\right.$, RT, $\delta$ in ppm) $\delta 10.2\left(\mathrm{CH}_{3}\right), 10.4\left(\mathrm{CH}_{3}\right), 19.9\left(\mathrm{CH}_{3}\right), 19.9\left(\mathrm{CH}_{3}\right), 20.5\left(\mathrm{CH}_{3}\right), 20.6\left(\mathrm{CH}_{3}\right), 22.8\left(\mathrm{CH}_{3}\right), 22.9$ $\left(\mathrm{CH}_{3}\right), 23.0\left(\mathrm{CH}_{3}\right), 23.1\left(\mathrm{CH}_{3}\right), 23.8\left(\mathrm{CH}_{3}\right), 24.2\left(\mathrm{CH}_{3}\right), 24.5\left(\mathrm{CH}_{3}\right), 25.6\left(\mathrm{CH}_{3}\right), 25.9\left(\mathrm{CH}_{3}\right), 26.1\left(\mathrm{CH}_{3}\right)$, 
$26.9\left(\mathrm{CH}_{3}\right), 27.4\left(\mathrm{CH}_{3}\right), 31.3(\mathrm{CH}), 31.4(\mathrm{CH}), 31.7(\mathrm{CH}), 32.1(\mathrm{CH}), 34.7(\mathrm{CH}), 34.8(\mathrm{CH}), 49.4(\mathrm{CH}), 52.7$ $(\mathrm{CH}), 120.6(\mathrm{CH}), 120.8(\mathrm{CH}), 121.5(\mathrm{CH}), 122.1(\mathrm{CH}), 126.8(\mathrm{CH}), 128.4(\mathrm{CH}), 134.1(\mathrm{CH}), 138.9(\mathrm{C}), 139.7$ (C), 142.0(C × 2), $145.2(C), 145.3(C), 145.4(C), 146.3(C), 148.3(C), 148.4(C), 148.5(C), 148.4(C), 148.5$ (C), $148.8(C), 152.0(C), 153.3(C)$; Anal. Calcd. for $\mathrm{C}_{47} \mathrm{H}_{69} \mathrm{ClGeN}_{2} \mathrm{~S}_{2}$ : C 70.28, H 8.78, N 3.49; found: C 69.99, H 8.72, N 3.88 .

\subsection{Single-Crystal X-ray Analysis of $\left.\mathrm{Ge}(\mathrm{S}) \mathrm{Cl} \mathrm{C}_{6} \mathrm{H}_{3}-2,6-\mathrm{Tip}_{2}\right\}\left(\mathrm{Im}^{\left.-i-\mathrm{Pr}_{2} \mathrm{Me}_{2}\right)} 3\right.$}

Crystals suitable for the X-ray crystallographic analysis of the germathioacid chloride (3) were obtained from benzene- $d_{6}$. The intensity data were collected on a Rigaku XtaLab P200 diffractometer (Rigaku, Tokyo, Japan) with multi-layer mirror mono chromated Mo K $\alpha$ radiation $(\lambda=0.71075 \AA)$. The structures were determined by direct methods (SHELXS-97) [23], and refined by full-matrix least-squares procedures on F2 for all reflections (SHELXL-97) [23]. All of the non-hydrogen atoms were refined anisotropically. All hydrogens were placed using AFIX instructions. All calculations were carried out using Yadokari-XG2009 [24]. Crystallographic data have been deposited into the Cambridge Crystallographic Data Centre, with deposition numbers CCDC 1851711 for compound 3. Copies of the data can be obtained free of charge via http://www.ccdc.cam.ac.uk/conts/retrieving.html (or from the Cambridge Crystallographic Data Centre, 12, Union Road, Cambridge, CB2 1EZ, U.K.; Fax: +44 1223 336033; e-mail: deposit@ccdc.cam.ac.uk).

Crystal data for $\mathrm{Ge}(\mathrm{S}) \mathrm{Cl}\left\{\mathrm{C}_{6} \mathrm{H}_{3}-2,6-\mathrm{Tip}_{2}\right\}\left(\mathrm{Im}_{-}-\mathrm{Pr}_{2} \mathrm{Me}_{2}\right)$ (3) $(123 \mathrm{~K}): \mathrm{C}_{47} \mathrm{H}_{69} \mathrm{ClGeN}_{2} \mathrm{~S}$, Fw 802.14, Monoclinic, Space group $P 2{ }_{1} / n$, colorless crystals, $a=9.3421(10), b=19.570(2), c=23.901(3) \AA$, $\beta=90.387(3)^{\circ}, V=4369.6(8) \AA^{3}, Z=2, D_{\text {calcd }}=1.219 \mathrm{Mg} / \mathrm{m}^{3}, R 1=0.0486(I>2 \sigma), w R 2=0.1243$ (all data), Goodness of Fit $(\mathrm{GOF})=0.906$.

\subsection{DFT Calculations}

Density functional theory (DFT) calculations were performed using the Gaussian 16 program package [25]. Geometry optimizations and vibrational analyses of all local equilibriums were performed using the B3LYP functional with a basis set of $6-31 G(d, p)$ for all atoms. The natural population analysis (NPA) [26], charge distribution, Wiberg bond index (WBI) [27], and second-order perturbation analysis were calculated with the natural bond orbital (NBO) program package at the B3LYP/6-31G(d,p) level of theory. Cartesian coordinates and energies of the computed structures are listed in the Supplementary Materials.

\section{Conclusions}

In conclusion, we have achieved the synthesis of germathioacid chloride without using nitrogen ligands. The nature of the bonds between the germanium atom and sulfur atom was investigated by $X$-ray analysis and DFT calculation. These experimental and theoretical results suggest that the Ge-S bond is a single bond with a partial double bond character. We hope that our research will help us clarify the nature of the Ge-S bond.

Supplementary Materials: The following are available online at http:/ /www.mdpi.com/2304-6740/6/3/76/s1. Figures S1 and S2: ${ }^{1} \mathrm{H}$ - and ${ }^{13} \mathrm{C}\left\{{ }^{1} \mathrm{H}\right\}-\mathrm{NMR}$ spectra of 2 and 3 in $\mathrm{C}_{6} \mathrm{D}_{6}$, Figure S3: Optimized geometries of germathioacid chloride 3 , Cartesian coordinates and energies of the computed structures, cif and check cif files of compound 3.

Author Contributions: Y.E., N.T. and M.U. conceived and designed the experiments; C.F. and Y.E. performed the experiments; Y.E. and N.T. performed the XRD analysis; K.M. performed the theoretical calculation; Y.E., K.M. and M.U. wrote the paper.

Funding: This research received no external funding.

Acknowledgments: The computations were performed by the Research Center for Computational Science, Okazaki, Japan.

Conflicts of Interest: The authors declare no conflict of interest. 


\section{References}

1. Power, P.P. Main-group elements as transition metal. Nature 2010, 463, 171-177. [CrossRef] [PubMed]

2. Lee, V.Y.; Sekiguchi, A. Organometallic Compounds of Low Coordinate Si, Ge, Sn and Pb: From Phantom Species to Stable Compounds; Wiley: Chichester, UK, 2010.

3. Tokitoh, N.; Okazaki, R. Recent advances in the chemistry of group 14-group 16 double bond compound. Adv. Organomet. Chem. 2001, 47, 121-166.

4. Brook, A.G.; Abdesaken, F.; Gutekunst, B.; Gutekunst, G.; Kallury, R.K. A solid silaethene: Isolation and characterization. J. Chem. Soc. Chem. Commun. 1981, 4, 191-192. [CrossRef]

5. West, R.; Fink, M.J.; Michl, J. Tetramesityldisilene, a stable compoundd containing a silicon-silicon double bond. Science 1981, 214, 1343-1344. [CrossRef] [PubMed]

6. Yoshifuji, M.; Shima, I.; Inamoto, N.; Hirotsu, K.; Higuchi, T. Synthesis and structure of bis(2,4,6-tri-tertbuthylphenyl)diphosphene: Isolation of a true phosphobenzene. J. Am. Chem. Soc. 1981, 103, 4587-4589. [CrossRef]

7. Okazaki, R.; Tokitoh, N. Heavy Ketones, the Heavier Element Congeners of a Ketone. Acc. Chem. Res. 2000, 33, 625-630. [CrossRef] [PubMed]

8. Fischer, R.C.; Power, P.P. $\pi$-Bonding and the Lone Pair Effect in Multiple Bonds involving Heavier Main Group Elements: Developments in the New Millennium. Chem. Rev. 2010, 110, 3877-3923. [CrossRef] [PubMed]

9. Veith, M.; Becker, S.; Huch, V. A Base-Stabilized Ge-S Double Bond. Angew. Chem. Int. Ed. Engl. 1989, 28, 1237-1238. [CrossRef]

10. Tokitoh, N.; Matsumoto, T.; Manmaru, K.; Okazaki, R. Synthesis and Crystal Structure of the First Stable Diarylgermanetione. J. Am. Chem. Soc. 1993, 115, 8855-8856. [CrossRef]

11. Matsumoto, T.; Tokitoh, N.; Okazaki, R. The First Kinetically Stabilized Germanethiones and Germaneselones: Syntheses, Structure, and Reactivities. J. Am. Chem. Soc. 1999, 121, 8811-8824. [CrossRef]

12. Ding, Y.; Ma, Q.; Usón, I.; Roesky, H.W.; Noltemeyer, M.; Schmidt, H.-G. Synthesis and Structures of $\left[\left\{\mathrm{HC}(\mathrm{CMeNAr})_{2}\right\} \mathrm{Ge}(\mathrm{S}) \mathrm{X}\right]\left(\mathrm{Ar}=2,6-i \mathrm{Pr}_{2} \mathrm{C}_{6} \mathrm{H}_{3}, \mathrm{X}=\mathrm{F}, \mathrm{Cl}, \mathrm{Me}\right)$ : Structurally Characterized Examples with a Formal Double Bond between Group 14 and 16 Elements Bearing a Halide. J. Am. Chem. Soc. 2002, 124, 8542-8543. [CrossRef] [PubMed]

13. Prashanth, B.; Singh, S. Concise access to iminophosphonamide stabilized heteroleptic germylenes: Chemical reactivity and structural investigation. Dalton Trans. 2016, 45, 6079-6087. [CrossRef] [PubMed]

14. Leung, W.-P.; Chong, K.-H.; Wu, Y.-S.; So, C.-W.; Chan, H.-S.; Mak, T.C.W. Synthesis of Chalcogeno[3-(pyrid2-yl)-1-azaallyl]germanium Complexes. Eur. J. Inorg. Chem. 2006, 808-812. [CrossRef]

15. Sinhababu, S.; Siwatch, R.K.; Mukherjee, G.; Rajaraman, G.; Nagendran, S. Aminotroponiminatogermaacid Halides with a $\mathrm{Ge}(\mathrm{E}) \mathrm{X}$ Moiety $(\mathrm{E}=\mathrm{S}, \mathrm{Se} ; \mathrm{X}=\mathrm{F}, \mathrm{Cl})$. Inorg. Chem. 2012, 51, 9240-9248. [CrossRef] [PubMed]

16. Xiong, Y.; Yao, S.; Inoue, S.; Berkefeld, A.; Driess, M. Taming the germyliumylidene [ClGe: $]^{+}$and germathionium $[\mathrm{ClGe}=\mathrm{S}]^{+}$ions by donor-acceptor stabilization using 1,8-bis(tributylphosphazenyl) naphthalene. Chem. Commun. 2012, 48, 12198-12200. [CrossRef] [PubMed]

17. Filippou, A.C.; Chernov, O.; Blom, B.; Stumpf, K.W.; Schnakenburg, G. Stable N-Heterocyclic Carbene Adducts of Arylchlorosilylenes and Their Germanium Homologues. Chem. Eur. J. 2010, 16, 2866-2872. [CrossRef] [PubMed]

18. Ossig, G.; Meller, A.; Brönneke, C.; Müller, O.; Schäfer, M.; Herbst-Irmer, R. Bis[(2-pyridyl)bis(trimethylsilyl) methyl-C,N]germanium(II): A Base-Stabilized Germylene and the Corresponding Germanethione, Germaneselenone, and Germanetellurone. Organometallics 1997, 16, 2116-2120. [CrossRef]

19. Li, L.; Fukawa, T.; Matsuo, T.; Hashizume, D.; Fueno, H.; Tanaka, K.; Tamao, K. A stable germanone as the first isolated heavy ketone with a terminal oxygen atom. Nat. Chem. 2012, 4, 361-365. [CrossRef] [PubMed]

20. Schiemenz, B.; Power, P.P. Synthesis of Sterically Encumbered Terphenyls and Characterization of Their Metal Derivatives $\mathrm{Et}_{2} \mathrm{OLiC}_{6} \mathrm{H}_{3}-2,6$-Trip 2 and $\mathrm{Me}_{2} \mathrm{SCuC}_{6} \mathrm{H}_{3}-2,6$-Trip 2 (Trip = 2,4,6-i- $\mathrm{Pr}_{3} \mathrm{C}_{6} \mathrm{H}_{2}{ }^{-}$). Organometallics 1996, 15, 958-964. [CrossRef]

21. Pu, L.; Olmstead, M.M.; Power, P.P. Synthesis and Characterization of the Monomeric Terphenyl-Metal Halides $\mathrm{Ge}(\mathrm{Cl})\left\{\mathrm{C}_{6} \mathrm{H}_{3}-2,6-\right.$ Trip 2$\}$ (Trip $\left.=\mathrm{C}_{6} \mathrm{H}_{2}-2,4,6-i-\mathrm{Pr}_{3}\right)$ and $\mathrm{Sn}(\mathrm{I})\left\{\mathrm{C}_{6} \mathrm{H}_{3}-2,6\right.$-Trip 2$\}$ and the Terphenyl-Metal Amide $\mathrm{Sn}\left\{\mathrm{N}\left(\mathrm{SiMe}_{3}\right)_{2}\right\}\left\{\mathrm{C}_{6} \mathrm{H}_{3}-2,6-\mathrm{Trip}_{2}\right\}$. Organometallics 1998, 17, 5602-5606. [CrossRef] 
22. Kuhn, N.; Kratz, Y. Synthesis of Imidazol-2-ylidenes by Reduction of Imidazole-2-(3H)-thiones. Synthesis 1993, 561-562. [CrossRef]

23. Sheldrick, G.M. SHELXS-97 and SHELXL-97; Program for the Solution of Crystal Structures; University of Göttingen: Göttingen, Germany, 1997.

24. Kabuto, C.; Akine, S.; Nemoto, T.; Kwon, E. Release of Software (Yadokari-XG 2009) for Crystal Structure Analyses. J. Cryst. Soc. Jpn. 2009, 51, 218-224. [CrossRef]

25. Frisch, M.J.; Trucks, G.W.; Schlegel, H.B.; Scuseria, G.E.; Robb, M.A.; Cheeseman, J.R.; Scalmani, G.; Barone, V.; Petersson, G.A.; Nakatsuji, H.; et al. Gaussian 16; Revision A.03; Gaussian, Inc.: Wallingford, CT, USA, 2016.

26. Reed, A.E.; Curtiss, L.A.; Weinhold, F. Intermolecular interactions from a natural bond orbital, donor-acceptor viewpoint. Chem. Rev. 1988, 88, 899-926. [CrossRef]

27. Sizova, O.V.; Skripnikov, L.V.; Sokolv, A.Y. Symmetry decomposition of quantum chemical bond orders. THEOCHEM 2008, 870, 1-9. [CrossRef]

(C) 2018 by the authors. Licensee MDPI, Basel, Switzerland. This article is an open access article distributed under the terms and conditions of the Creative Commons Attribution (CC BY) license (http://creativecommons.org/licenses/by/4.0/). 